\title{
US in vitro fertilization in limbo according to OTA
}

\section{Washington}

INFERTILITY therapy has become big business in the United States. According to a new report* by the congressional Office of Technology Assessment (OTA), US spending on medical treatment to combat infertility amounted to $\$ 1,000$ million in 1987. But, for a variety of social and legal reasons, US research on treatments to improve reproductive success has not kept pace with the growing demand for the technology.

The number of infertile couples in the United States is estimated to have remained constant over the past 15 years at about 2.4 million, defined as those who have not conceived after 12 months of intercourse without contraception.

The report also says that about 20 per cent of all infertility is caused by sexually transmitted diseases.

If the percentage of infertile couples has not changed, the numbers seeking treatment have increased substantially. In 1968 , there were 600,000 physical office visits for infertility services, but by 1984 the number had increased to 1.6 million.

Conventional medical and surgical treatment still seems to be the most common approach. But new non-coital technology, specifically in vitro fertilization (IVF) and gamete intrafallopian transfer (GIFT), are gaining acceptance, witnessed by the growing number of clinics providing these services. But the OTA points out that the federal government has virtually no role in supporting their development nor in monitoring their success.

Private organizations such as the American Fertility Society and the American College of Obstetricians and Gynecologists have supported some evaluations of IVF clinics, but OTA concludes that there is no way at present to tell whether IVF is an experimental or proven medical therapy.

Part of the explanation goes back to the 1974 National Research Award Act, which set up the National Commission for the Protection of Human Subjects of Biomedical and Behavioral Research. That commission instituted local reviews of experiments involving human subjects by means of Institutional Review Boards, and also called for an ethical advisory board $(\mathrm{EAB})$ within the Department of Health and Human Services (HHS). EAB was given authority to review grant applications for IVF research projects on a case-by-case basis, without which grants would be prohibited by HHS.

But EAB disappeared in 1980 , as its charter came up for what should have been routine renewal at the end of the Carter administration and the then HHS
Secretary Patricia Harris let it expire. The board had become politically contentious because of its suggestion that certain types of research on IVF might proceed without review, which caused uproar from the potent US anti-abortion movement. The Reagan administration has not re-established EAB, although technically it is required to do so by HHS regulations.

Without a functioning board, the National Institutes of Health (NIH) cannot make grants for IVF research. Under normal circumstances, NIH reckon they would receive 100 grant applications a year for IVF-related research. NIH have tried several ways of breaking this legal logjam, including reviewing of IVF research proposals before passing them on to HHS for approval by the non-existent EAB. So far, NIH have had no success.

But the Congress may be ready to intervene, in part because of the OTA report. The House of Representatives subcommittee on regulation and business opportunities of the Small Business Committee began hearings on 1 June on the commercialization of reproductive technology, emphasizing the need to offer at least some protection to consumers of IVF services.

As health insurance coverage for IVF is uneven at best, it is an expensive gamble. OTA estimates that, on average, IVF can provide a baby for one couple in ten at an average cost of some $\$ 22,000$.

Joseph Palca

* Infertility: Medical and Social Choices. US Congress, Office of Technology Assessment, Washington, $D C$ 1988

\section{UK nuclear waste strategists still facing public suspicion}

\section{London}

BRITAIN's nuclear power industry continues to struggle in its efforts to gain public acceptance for a waste disposal strategy. Earlier this month, the local authority in Cumbria refused to grant permission for a test borehole at the site of the Sellafield nuclear complex, in spite of assurances from the operators, British Nuclear Fuels (BNFL), that the borehole would be used merely to obtain information about the site's geology as part of continuing investigations to assess the area's suitability for a deep depository for intermediate level waste. BNFL is still considering their response to the rejection.

The industry has ploughed tens of millions of pounds into its attempts to find a publicly acceptable means of disposing of low and intermediate level nuclear waste. Last year, in the face of severe local opposition, the Nuclear Industry Radioactive Waste Executive, Nirex, suddenly abandoned its investigations of four sites for shallow dumps for low-level waste in favour of deep depository for both low and intermediate level waste. Six months later, in November, Nirex produced a discussion document outlining the options available and inviting responses from interested parties. Nirex says it has sent out some 60,000 documents and has received around 800 responses, the deadline for which has been extended from the end of last month until mid-July.

The options under consideration are for a deep-mined cavity under land using conventional mining techniques; an off-shore sub-seabed cavity reached by tunnels on the coast; or an offshore, sub-seabed cavity accessed from the sea's surface by a drilling platform or artificial island. Nirex is thought to favour the first option, and experts have doubts about the feasibility of the third.

The government's Radioactive Waste Management Advisory Committee (RWMAC), whose chairman is Professor John Knill, of Imperial College and the chairman-elect of the Natural Environment Research Council, published its response to the Nirex document last week. The committee is not impressed with the government's current record on waste disposal, and has "viewed with continuing concern the several shifts in government waste disposal policy in recent years which have both caused delay in achieving suitable provision for disposal within an appropriate timescale and contributed to the public uncertaintly over the practibility of any solution". The committee also wonders if Nirex should acquire in-house geological expertise instead of using the British Geological Survey, which as advisers to the government might be construed as having a conflict of interests.

Questions are also arising about the future of Nirex once the electricity supply industry is in private hands. Under government proposals, the Central Electricity Generating Board, which pays 42.5 per cent of Nirex's costs, is to be sold off as two companies, the larger of which will retain the nuclear capacity. Doubts are already being raised about the willingness or ability of the nuclear company to invest substantially in research. One suggestion is that the government would transfer responsibility for waste disposal to BNFL (which also pays 42.5 per cent of Nirex's costs), which is to remain in government hands and which produces most of the nation's nuclear waste. Simon Hadlington 